\title{
İsmihan ve Mezid'in Hikâyesi: Osmanlı Toplumunda Mahremin Kamusal Alana Taşınma Biçimi Hakkında Bir Değerlendirme
}

\author{
Prof. Dr. Bayram Ürekli \\ Selçuk Üniversitesi, Edebiyat Fakültesi \\ Tarih Bölümü \\ burekli@selcuk.edu.tr
}

\author{
Muhammed Özler \\ Selçuk Üniversitesi, Sosyal Bilimler Enstitüsü \\ Tarih Ana Bilim Dalı, Doktora Öğrencisi \\ mhmmdozlr@gmail.com
}

Öz

Osmanlı toplumunun kamusal ve özel alan kavramlarını nasıl anlamlandırdığını tespit etmenin en doğru yolu hiç şüphesiz toplumu oluşturan bireylerin bu kavramları nasıl tanımladıklarını açıklamakla mümkün olacaktır. Bu tanımlara ulaşmak için ise şer'iye sicili olarak bilinen, kadılar tarafından tutulan ve mahkeme tutanakları olarak ifade edilen kayıtların satır aralarına bakmak gerekir. Mahkeme tutanakları bireyin gündelik yaşamının ipuçlarını yansıtması ve toplumun sesinin en çok duyulduğu metinleri içinde barındırması bakımından mahrem ve kamusal alan kavramlarının açıklanmasında oldukça kullanışlı kaynaklar olarak değerlendirilebilir. Bu bağlamda bu çalışmada mahkeme tutanaklarından alınan örnek bir olay üzerinden iki kişi arasında yaşanan mahrem bir olayın kamusal alana taşınması süreci değerlendirilmeye çalışılmıştır. Ayrıca bu değerlendirmeyi sağlıklı ve işlevsel kılmak amacıyla Osmanlı taşrasında hukukun işleyiş̧ biçimi ve mahalle denetimi gibi birtakım faktörler de göz önünde bulundurulmuştur.

Anahtar Kelimeler: Kamusal alan, mahkeme, mahremiyet, mahalle, Osmanlı toplumu.

\section{The Story of Ismihan and Yezid: An Evaluation of Moving from Private (Mahrem) to Public Space in Ottoman Society}

\begin{abstract}
The best way to determine how Ottoman society uses the concepts of public and private sphere would undoubtedly be possible by explaining how the individuals constituting the society define these concepts. In order to reach these definitions, it is necessary to read between the lines of the records, which are known as sheriyya registry, kept by the kadis (Muslim judges) and expressed as court records. Court proceedings, in which the voice of the society is heard and the clues on the daily lives of individuals are reflected, can be considered as very useful sources for explaining the concepts of private and public space. In this context, this study aimed to evaluate the process of transferring a private event between two people to the public space through a case study taken from court records. Furthermore, in order to make this assessment healthy and functional, a number of factors such as the functioning of the law and neighborhood supervision in the Ottoman provinces were taken into consideration.
\end{abstract}

Keywords: Public space, court, privacy, neighborhood, Ottoman society. 


\section{GíRiş}

Mahkeme tutanaklarından aldığımız örnek olayın gerçekleştiği yer, Anadolu Selçuklu Devleti ve Karamanoğulları Beyliği'ne başkentlik yapan, Osmanlılar döneminde teşkil edilen Karaman Beylerbeyiliği'nin paşa sancağı olan, nüfus bakımından orta büyüklükte, ticaret yolları üzerinde önemli bir uğrak merkezi konumunda yer alan, Hac ibadeti amaciyla kutsal topraklara giden hacılara, ticaret kervanlarına ve doğuya sefere çıkan ordulara hizmet eden Konya şehridir. Bünyesinde zengin tarihsel ve kültürel birikimi muhafaza eden, mahalleleri, çarşı ve pazarları, dini mekânlarıyla oldukça canlı bir görüntü çizen Konya şehrinde yaşayan bireylerin gündelik yaşamlarının da hayli hareketli olabileceği düşünülmektedir. Evlenenler, boşananlar, kendilerine kalan mirası paylaşmaya çalışanlar, hayır işlerine yönelenler, kendi işiyle meşgul olanlar, birbirleriyle kavga edenler, hırsızlık yapanlar, cinayet işleyenler ve diğerleri bu hareketli gündelik yaşamın bir parçasını oluşturmaktadır. Bu bağlamda şehrin gündelik işlerine bir şekilde müdahil olanların hayatları aslında parçası oldukları toplumun ve dönemin tarihinin ipuçlarını içinde barındırmaktadır.

Konya'nın Ferhuniye Mahallesi'nde yaşayan İsmihan ile onun etrafında gelişen olaylar ve bu olayların gündelik yaşama dönük yönleri yukarıda belirtilen hususlar çerçevesinde önem taşımaktadır. Yalnız yaşayan Müslüman bir kadının evine bir erkeğin girmesiyle bağlantılı olaylar, Osmanlı mahallesinin yapısını ve kadı mahkemesinin işleyişini yansıtan çok boyutlu bir hikâyeye dönüşmüştür. İsmihan ve Mezid arasındaki yasak aşkın meraklı gözler tarafından izlenmesi ve mahallelinin kendi kamusal alanlarını tehdit eden bu tip eylemlere karşı gösterdiği tepki bir bütün olarak değerlendirildiğinde bireylerin davranışlarının hem mahallede yaşayanların hem de mahkemenin başka bir deyişle devlet otoritesinin denetimine tabi tutulduğunu göstermesi bakımından önemli olduğunu düşündürebilir.

Bu çalışmada, XVII. yüzyılın ikinci yarısında Konya'da, toplumsal ahlaki normlara ve mahalle denetimine karşı çıkan İsmihan ve Mezid'in yasak aşkı konu edilmiştir. Böylece 1673 yılı Ocak ayında Mezid'in İsmihan'ın evinde yakalanması ile bunun sonrasında yaşananlar üzerine mahkemenin ve toplumsal kontrol mekanizmasının işleyişinin nasıl olduğunu ortaya koyarak bireylerin mekân kavramını algılayışını incelemek makalenin temel problematiğini oluşturmaktadır.

\section{Olay, Mekân ve Mahkeme}

1672-1673 yılı Konya Mahkemesi tutanaklarında yanlışlıkla kaydedildiği belirtilen bir kayda göre Konya'nın Ferhuniye Mahallesi'nde yaşayan Abdi oğlu Hacı Nurullah 1673 yılı Ocak ayının yirmi dokuzunda mahkemeye müracaat ederek Mezid'den şikâyetçi olmuştur. ${ }^{1}$ Mezid'i, evinin duvarına çıkarak ailesini izlemekle ve yan komşusu İsmihan'ın evine hıyanet kastıyla girmekle itham etmektedir (KŞS 16/116). Bu suçlamanın temelinde hem İsmihan'ın hem de kendisinin mahrem/özel alanının Mezid tarafından ihlal edilmesi eylemi yatmaktaydı. Ayrıca Osmanlı kanunnameleri birinin evini izlemeyi suç olarak kabul etmekte ve bu fiili işleyenlere 20 akçe ceza öngörmekteydi (Akgündüz, 1992, s. 328). Evleri izlemenin ceza gerektirecek bir hareket olarak tanımlanması devletin aile mahremiyetini korumak istemesiyle ilişkilidir. Şehri meydana getiren mahallelerin içinde yer alan meskenler mahrem

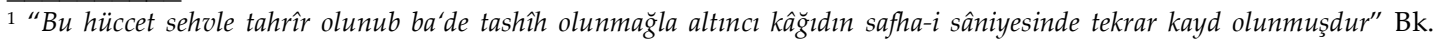
(KŞS 16/116). Biz öncelikle ilk kayıt üzerinden değerlendirmeler yapma yolunu tercih ettik. Daha sonra aynı olay hakkındaki ikinci kayıtta görülen farklılıkları ortaya koymaya çalıştık. 
alanı oluşturan birimlerdi ve bu alanlara yabancıların izinsiz olarak dâhil olması mahremiyet sınırlarının aşılması olarak değerlendirilerek tecavüz konusu sayılıyordu (Ergenç, 2015, s. 17; Yılmaz, 1995, s. 147-148; Tekgül, 2013, 418). Bu bağlamda Nurullah mahkemede konuşurken menzil (ev) ve duvar kelimelerini kullanıyor ve böylelikle Mezid'in hem İsmihan'a ait evin sınırlarına dahil olarak onun mahrem alanının hem de duvar vasıtasıyla ailesinin gözetlendiğini söyleyerek kendi mahrem alanının sınırlarının aşıldığını belirtiyordu. Bireylere ait ev ve duvar gibi sahiplerine özgü birimlerin mahrem alanlarının bir parçası olduğu gerçeği Nurullah'ın sözleriyle kesinlik kazanıyordu. Bu durum esasen mahrem alan algısının evden başlayarak duvar ve sokak kapısına doğru genişleyen bir özel yaşam alanının dokunulmazlığına işaret etmektedir. Evin mahrem alanı kapının sokağa açılmasıyla birlikte sona erer ve şeffaflaşarak kamusal olarak adlandırılan mahalleye ve oradan da şehir hayatıyla karşılaşır. Kamusallık ile mahrem alan arasında daima karşılıklı bir ilişkinin olduğu gözden kaçırılmamalıdır (Habermas, 2003, s. 279). Bu bağlamda özel/mahrem alan ile kamusal alan kavramları zıt kutuplar olarak görünseler de gündelik hayatın sürüp gittiği iki temel alanı meydana getirmeleri bakımından birbirinden bağımsız olarak düşünülemez.

Mahkeme devam ederken tanıkların olaya müdahil olmasıyla birlikte Mezid'in İsmihan'ın evine girip çıktı̆̆ı ortaya çıkmıştı. Dolayısıyla mahkemenin gidişatı Mezid açısından olumsuz ilerlemeye başlamıştı. Dava kaydına göre Mezid, 28 Ocak 1673 günü sabah ile öğle vakitleri arasında İsmihan'ın evine girmiştir. Ancak mahalleli bundan haberdar olmuş ve Mezid'i yakalamak için harekete geçmiştir. Ahali Mezid'i Nurullah'ın duvarının üzerine çıkmış bir vaziyette görmüştü. Davaya İsmihan'ın tarafından bakılınca o da masum bir kadın olarak görülüyordu ve hiç tanımadığı biri evine girmişti. Fakat bir aşamada şahitler tarafından İsmihan'ın iyi bir kadın olmadığı gündeme getirilmişti. Şahitler İsmihan hakkında konuşurken "Mezid daima İsmihan'ın evine gelir, İsmihan kendi halinde değildir" ifadelerini kullanmaktaydılar (KSŞ 16/116). Bu durum mahkemenin bireyler hakkında karar verirken kişilerin yaşamlarını sürdürdüğü mahalle halkının fikirlerinden de yararlandığını göstermektedir. Ayrıca burada tanıklığın mahkemenin işleyişinde son derece önemli bir role sahip olduğunu görüyoruz. Nurullah'ın ifadesine göre mahkemenin başında İsmihan masum bir kadındı ve Mezid'in İsmihan'ın evine hıyanet kastıyla girdiğinin de altını çizmişti. Ancak şahitlerin ifadeleri ile birlikte İsmihan'ın masum bir kadın olduğu savı onun kötü bir kadın olduğu sorunu ile yer değiştirmiştir. Bu nedenle çoğu kez mahkemede kanıtlar ve görgü tanıklarının sözleri değerlendirilirken, bir de sanığın yaşamakta olduğu mahallesinde nasıl tanındığı araştırılmaktaydı (Ergenç, 1984, s. 74). Bu araştırma işlemi mahkeme metinlerinde bireylerin "keyfiyet-i hallerinin mahallelisinden sual olunmast" gibi standart ifadelerle betimleniyordu. Bu işlem başka bir deyişle kişinin "hal ve gidişatının" sorgulanmasıydı. Şahitler tarafından İsmihan'ın kendi halinde olmadığının söylenmesi ve sergilediği davranışlar nedeniyle toplumsal ilkelere uymadığı, içinde yaşadığı topluluğun huzurunu kaçırdığı ve ahlaki vasıflarının zayıf olduğuna işaret ediyordu. Osmanlı toplumunda kendi halinde olmamak mahkeme tarafından "sî-i hâl" kapsamında değerlendiriliyordu. Bir birey hakkında görüşüne başvurulanların ifadeleri gerekçeleriyle birlikte mahkeme tarafından hüsn-i hâl veya sû-i hâl şeklinde kalıp ifadelerle ve kesin bir ayrımla dile getirilmekteydi (Tok, 2005, s. 158-162; Kaplanoğlu, 2012, s. 50-52; Çetin, 2019, s. 63). Mahkemeye göre, hakkında olumlu görüş belirtilenlerin isnat edilen fiili işleme ihtimallerinin olmadığ ya da çok düşük olduğu kabul edilir ve kişinin hüsn-i hâl üzere olduğu belirtilirdi. Aksi durumda ise bireyin sû-i hâl üzere olduğu düşünülür ve bu şekilde 
kayda geçirilirdi. 1672-1673 yılına ait mahkeme tutanaklarına göre pek çok kişi hakkında komşularının fikirlerine başvurulmuş olması bu uygulamanın mahkeme tarafından etkin bir şekilde kullanıldığını göstermektedir (KŞS 16/88; KŞS 16/77; KŞS 16/132).

Konya'nın Bayburt Kazası'na bağlı Arpalar Köyü'nde yaşayan Mustafa kızı Hatice Hatun kendisine bir kutu helva gönderdiği için Sinan Çelebi'den şikâyetçi olmuştu. Olayın gerçekleştiği yerin bir köy olması muhtemelen olayın kısa sürede köy halkı tarafından duyulmasına ve Hatice'nin bir erkekle adının çıkmasına yol açmış olmalıdır. Kadı, Sinan Çelebi ve Hatice'nin durumlarının Arpalar Köyü ahalisinden sorulmasını istediğinde köylüler her ikisinin de kendi hallerinde iyi insanlar olduklarını belirtmişlerdir (KŞS 16/88). Başka bir örnekte ise Konya Subaşısı Abbas Ağa tarafından mahkemeye getirilen Halil evine fahişe getirmek ve şarap içmekle suçlanıyordu. Ayn mahallede yaşayan kişilere Halil'in kişiliği soruldu; adamlar kadıya; "Şimdiye kadar Halil'in hukuka aykırı herhangi bir hareketini görmedik, kendi halinde iyi bir insandir" dediler (Tutar, 2018, s. 127). Nasuh ismindeki biri benzer bir nedenle suçlandığında, hal ve gidişatı komşularından sorulmuş, sonuç Nasuh için olumsuz çıkmıştı: "Nasuh'un fahişelerle görüştüğünü bildiklerini ve zina yapmaktan çekinmeyen kötü biri olduğunu söylediler" (KSŞ 16/77). Ayrıca mahalleli, mahalle halkının huzurunu bozan, ahlak ve namus dışı davranışlarda bulunan kişileri, mahkemeye başvurarak mahalleden ihraç etme hakkını bir koz olarak kullanabiliyordu (Çetin, 2014, s. 45; Ergenç, 1984, s. 75; Kütükoğlu, 2018, s. 24). Evine Ayşe ve Alime ismindeki kadınları getirip pezevenklik yaptığı iddiası ile mahkemeye getirilen Nebi hakkında komşuları şunları söylemişlerdi: "Nebi, Ayşe ve Alime'yi evine getirir ve pezevenklik yapar, onun yüzünden mescide gidip namaz kılamaz olduk. Mahalleden ihraç olunsun" (KŞS 16/132). Bu örnekler mahalle halkının ahlaki değerlerden yoksun olan kişilere karşı mahkemeyi devreye sokmakla birlikte yaşadıkları toplumun huzurunun zedelenmesini engellemek istediklerini de göstermektedir. Başka bir deyişle hoş karşılanmayan davranış biçimlerinin yaygınlaşmasını aile birlikteliklerine karşı büyük bir tehdit olarak görüyorlardı. Bu nedenledir ki 1672-1673 yılında Konyalılar, pezevenklik yaptıkları gerekçesiyle Nebi, Mustafa, Pirli ve Mihriban ismindeki kişilerin ikamet ettikleri mahallelerinden kovulmalarını istemişlerdi (KŞŞ 16/132; KŞS 16/147; KŞS 16/161; KŞS 16/167). Bazen de mahalleli bunu açıktan yapmaz, yetkilileri göreve davet etmek için şikâyetçi olmak istedikleri kişilerin kapılarına ya boynuz asarlar ya da katran sürerlerdi (Yağcı, 2005, s. 65; Aköz, 2016, s. 45).

Gerçekten İsmihan kötü bir kadın mıydı? Ya da tek başına hayatını sürdüren bir kadının kendi muhitlerinde yaşamasını istemedikleri için mahalle sakinleri ona iftira $\mathrm{m} ı$ atıyordu? Yanlışlıkla kaydedildiği ifade edilen mahkeme kaydında İsmihan hakkında çok fazla bilgi yoktur. Mevcut bilgilere göre İsmihan Konya'nın Ferhuniye Mahallesi'nde yani mahkemeye başvuran Nurullah ile aynı mahallede ikamet ediyordu. Hatta komşu idiler. Osmanlı mahkeme kayıtlarında genellikle bireylerin kimlikleri babalarının isimleriyle birlikte anılmasına rağmen mahkeme İsmihan'ı şu şekilde betimlemişti: "Ferhuniye Mahallesi'nde sâkine İsmihan bint (boş) nâm hatun". Ancak mahkeme kayttları incelendiğinde Ferhuniye Mahallesi'nde yaşayan İsmihan bint Ahmet Beşe ismindeki bir kadının mahkemeye gelerek evini Süleyman Çelebi'ye sattığı görülüyor (KŞS 16/61). Satış işlemi kaydının şahitler kısmında tanıdık bir isme rastlanmaktadır. Bu isim Ferhuniye Mahallesi'nden Hacı Abdi oğlu Hacı Nurullah'tı. Yani Mezid'i dava eden kişinin ta kendisi. Nurullah'ın Ferhuniye Mahallesi'nde ikamet etmesi, Ahmed kızı İsmihan'ın ev satışı işleminde şahit olarak bulunması onun İsmihan'nın evinin konumunu bildiğini ve İsmihan'ı tanıdığını göstermesi bakımından önemli bir bilgi olarak değerlendirilebilir. Daha da önemlisi 1672-1673 yılı 
mahkeme kayıtlarında Ferhuniye Mahallesi'nde ikamet eden İsmihan isminde başka bir kadına rastlanmaması örnek olayımızın kahramanıyla ev satışı işlemini gerçekleştiren İsmihan'ın aynı kişi olabileceği ve dolayısıyla İsmihan'ın babasının isminin Ahmet olabileceğini düşündürmektedir. Ayrıca mahkeme kayıtlarının halkın tamamına dair bilgileri sunmuyor oluşu İsmihan adında başka bir kadının olmadığı sonucuna ulaşmamızı zorlaştırsa da Hacı Nurullah'ın satış işleminde şahit olarak bulunması olasılıkları güçlendirmemiz açısından önem arz etmektedir. Bu eksik kimlik tanımından İsmihan'ın Ferhuniye Mahallesi'nde yaşadığı bilgisi dışında ulaşacağımız başka bir bilgi ise İsmihan'ın olgunluk çağına ulaşmış olduğudur. Çünkü Osmanlı toplumunda kadınların erişkinliğini gösteren "hâtun" kelimesi yaygin olarak kullaniliyordu (Pierce, 2000, s. 173). Ayrıca mahkemede satış işlemi için vasisinin değil de kendisinin bulunması onun yetişkin bir kadın olduğunu göstermektedir. Ancak İsmihan'ın evli veya dul olduğuna dair herhangi bir bilgiye ulaşamamakla birlikte onun tek başına yaşayan dul bir kadın olduğunu varsaymak daha doğru bir yaklaşım olabilir. Çünkü 1672-1673 yılı mahkeme tutanaklarına yansıdığı şekliyle İsmihan günlük yaşamında kararlarını kendi alıyordu. Yine İsmihan'ın isminin geçtiği mahkeme tutanaklarında onunla ailevi bağı olan herhangi bir kişiye rastlanmamış olması İsmihan'ın yalnız yaşayan dul bir kadın olduğu savını güçlendirmektedir. Ayrıca Nurullah mahkemede şikâyetini dile getirirken İsmihan'ın eşinden söz etmemektedir. Herhalde İsmihan evli bir kadın olsaydı Nurullah bu bilgiyi mahkemeye aktarmaktan çekinmezdi. Mezid ise "El-Hâc Mezid bin Abdülcelil" şeklinde babasının ismiyle birlikte kaydedilmiş ve hacı unvanı ile birlikte anılıyordu. Ancak hacılık gibi prestij getiren bir unvana sahip olan Mezid'in bir kadının evine girdiği ve kadınla sürekli olarak görüştüğü iddiaları göz önüne alınırsa sahip olduğu unvanın getirdiği saygınlığı yitirmek üzere olduğu düşünülebilir.

Olayın kahramanları hakkında bildiklerimiz şimdilik bu kadar olmakla birlikte kâtibin mahkeme tutanağının üzerine kaydın yanlışlıkla tutulduğu ve sonradan başka bir sayfaya yazıldığını belirten notundan yola çıkarak İsmihan ve Mezid hakkındaki yeni bilgilere ulaşmayı ümit ederken olayın daha ayrıntılı bir tasviriyle karşılaştık. Bundan sonraki bölümde, kaleme alınan yeni tutanağı inceleyerek iki kayıt arasındaki farklılıkları göz önünde bulundurup yeni bir çerçeve çizmeye çalışacağız.

\section{Mahkeme Metinlerinin Yapısı ve Olayın Yeniden Yazımı Üzerine}

Mahkeme kayıtlarının genelinde metinlerin giriş ve sonuç kısımları bir takım kalıp ifadelerden oluşmaktadır. Giriş kısmı kişinin ikamet ettiği şehir ve mahallesi, kendi ismiyle birlikte babasının isminin belirtilmesi yani kimlik bilgileri ile başlamaktadır. Sonuç bölümü ise mahkemede görüşülen meselenin kayıt altına alındığı, kayıt tarihi ve şahitlerin isimlerinin yazılması ile son bulmaktadır. Bu standart kalıpların yer aldığı kısımlar kâtiplerin çabucak üstesinden geldikleri bölümler olmalıdır. Asıl mesele mahkemeye taşınan sorunun derli toplu bir şekilde özetlenerek metne dökülmesi idi. Bu anlatının metne dökülmesinde kadının takip ettiği yargılama usulü çok önemliydi. İlber Ortaylı kadının yargılama usulünü şöyle ifade etmektedir:

"Kadı kendisine müracaat edilib, davayı görmek istediğinde ilk önce davacıyı dinler; bundan sonra davalıyı dinler. Sonra davalıya davacının iddiası ile ilgili sorular sorar. Ĕ̆er davalı müddeînin iddiasını kabul ederse karar safhasına geçilir ve mesele vuzuha kavuşur. Gerek ceza davalarında, gerekse bizim hussusî hukuk dediğimiz alana giren 
davalarda davalının ikrarı mühimdir ve derhal zabta geçirilmesi gerektir. Ĕ̆ger davalı iddiayı reddederse bu takdirde kadı davacıya iddiasını ispat babında (beyyine külfeti ona ait olduğu anlaşıllyor) hukuki delil getiremez veya lehine şahidler bulamaz ise, onun talebi üzerine kadı davalıya yemin etmesini emreder. Bu yemin iddianın doğru veya yanlış olduğu konusundadır. Ĕ̆er davalı yemin ederse dava düşer. Ĕ̆er yemin etmeyi reddederse o takdirde hüküm davacı lehine verilecektir" (Ortaylı, 1994, s. 56-57).

Kadı yargılamasını bu usul üzere yapıyor ve doğru yargılama yönteminin gereklerinin yerine getirildiğini gösteren ögeleri metne yerleştiriyordu. Yine kadıların metinleri oluşturmasını kolaylaştıran birtakım yardımcı kitaplar ve kaynaklar vardı. Fâtih Sultan Mehmed döneminden itibaren Molla Hüsrev'in Dürerü'l-hükkâm, Kanûnî Sultan Süleyman devrinden itibaren ise İbrâhim el-Halebî'nin Mülteka'l-ebhur adlı eserleri mahkemelerin kullandığı bilgi kaynakları olarak bilinmektedir. Ayrıca resmi ve özel kanunname derlemeleri ve başşehirden gönderilen münferit fermanlar da kadılara örfî hukuk uygulamalarında yardımcı olan kaynakların başında geliyordu (Aydın, 2003, s. 342). Ancak kadı ve kâtipler en çok iç içe geçmiş olaylarla sarmalanmış, vak'alara şahit olanların konuşmalarıyla desteklenmiş davaları kayda geçirirken zorlanıyor olmalıdırlar. Çünkü bu tür davalarda bir tür zaman kargaşası yaşanıyordu. Mahkeme kayıtlarındaki davalar tek seferde karara bağlanmış gibi görünse de İsmihan ve Mezid'in hikâyesi gibi karmaşık ve çok evreli davalarda zaman kavramından ziyade meselenin çözüme kavuşturulma biçimi daha çok önemseniyordu. Bu tür davalar gerçekte birkaç oturum süren, belki de ara verilerek ek kanıt aramak ve mahkeme önüne getirilemeyen fiziksel kantları yerinde incelemek üzere insanların görevlendirildiği bir yapıya sahipti. Ayrıca bu tür karmaşık olayların kayda geçirilmesinin kolaylaştırılması için "sak mecmuaları" adı verilen yol gösterici kitaplardan yardım alınıyordu. Sak mecmuaları uzun yıllar mahkemelerde görev yapmış kişiler tarafından oluşturuluyor ve genellikle üst rütbeli ilmiye mensupları tarafından tashih edilmekteydi (Kaya, 2008, s. 587).

Kâtip tarafından yanlışlıkla tutulduğu ifade edilen mahkeme kaydı yukarıda ifade ettiğimiz kadı'nın yargılama usulü ve mahkeme metinlerinin oluşturulmasında takip edilen yöntemin pratiğe dökülmüş halini gözler önüne sermesine rağmen kâtibin bu kaydın yanlışlıkla tutulduğunu belirtmesi pek inandırıcı gelmemektedir. Çünkü kayıtta davalı, davacı, olayın mahiyeti, tanıkların ifadesi ve şahitlerin isimleri eksiksiz olarak bulunuyordu. Üstelik bu kayıt 1672-1673 yılına ait mahkeme kayıtları arasında uzun sayılabilecek bir hacme sahipti ve yarım da bırakılmamıştı. Muhtemelen İsmihan ve Mezid arasında yaşananlar duyulmuş ve kadı bu konunun sıradan bir haneye tecavüz olayı olarak kalmasını istememişti. Şahitlerin ifadeleriyle birlikte İsmihan'ın kötü bir kadın olduğuna dair iddiaların ortaya atılması da nikâhsız bir ilişkiye göz yummak istemeyen kadı'nın meseleyi yeniden araştırmak istemesine yol açmış olabilir. Öne sürülen bu düşünceler sadece birer tahminden ibaret olmakla birlikte ilk kaydın iptal edilip ikinci kez kaleme alınmasının asıl sebebini meseleye Konya müteselliminin dahil olmasıyla ilişkilendirmek daha mantıklı görülmektedir. İkinci kayıtta davacı pozisyonunda Konya Mütesellimi Mahmud Ağa'nın görülmesi İsmihan ve Mezid arasında yaşananların çabucak duyulduğu ve Mahmud Ağa'ya iletildiğini göstermektedir. Çünkü Osmanlı pratiğinde sancakbeyi, subaşı ve mütesellim gibi yerel idareciler kendilerine haber verildiğinde ya da bir duyum aldıklarında hukuki süreçlere müdahil olabiliyorlardı (Kavaklı, 2013, s. 121; Taş, 2007, s. 190). 
Kaydın giriş kısmındaki anlatıya göre Mezid ve İsmihan'ın davasının soruşturması için Mevlana Mehmed Efendi'nin (Fahrü'l-Müderrisin) görevlendirildiği ve Mütesellim Mahmud Ağa'nın huzurunda konunun görüşülmeye başlandı̆̆ı anlaşılıyor. İlk dava kaydındaki bilgilere göre Nurullah, Mezid hakkında dava açmıştı. Ancak ikinci davada şikâyetçi tarafın ismi ve konumu hakkında ciddi bir değişiklik görülmektedir. Bu kez Mütesellim Mahmud Ağa, Mezid ve İsimihan hakkında şikâyetçi olmuştu (KŞS 16/128). Ayrıca ilk kayıtta Nurullah sadece Mezid hakkında şikâyette bulunmuştu. Yanlışlıkla düzenlendiği belirtilen kayıtta tanıkların olaya müdahil olması ile birlikte İsmihan hakkında namus üzerinden bir töhmet oluşmuştu. Töhmet kesin olarak ispat edilmediği halde zan ve şüpheye dayalı olarak birine suç isnadında bulunmayı ifade etmekle birlikte Osmanlı toplumunda töhmetli olmak muhtemelen kişinin saygınlığına sürülmüş bir leke olarak değerlendiriliyordu. Çünkü birini suçlamak, suçlanan kişinin saygınlığını tartışmaya açmakla eş değerdi. Suçlanan kişilerden birinin kadın ve suçlama unsurunun da namusla ilişkilendirilmeye müsait olduğu düşünülürse İsmihan'ın saygınlığını yitirmekle karşı kaşıya kaldığı akla gelebilir. Bu töhmetin oluşmasında şahitlerin "Mezid sürekli olarak İsmihan'ın evine gelir, İsmihan iyi bir kadın değildir" sözleri etkili olmuştu. Başka bir ifadeyle şahitlerin ifadeleri ile desteklenen bu ciddi suçlama ikinci kayıtta İsmihan'ı da mahkemede aleyhinde dava açılan bir kadın konumuna düşürmüştür. Mezid ve İsmihan hakkında dava açan Mahmud Ağa'nın ilk sözleri şunlardı; "İsmihan ile Mezid'in birbirlerine namahrem olmalarına rağmen iki seneden beri görüştüklerini duydum". Mezid'in İsmihan'ın evine gelmesi toplum nezdinde yankı uyandırmış olmalı ki Mahmud Ağa ikili hakkında bir araştırma yaptırmış ve birbirlerine namahrem olan iki kişinin ilişkisinden haberdar olanlardan bilgi almıştı. Bildiklerini söyleyenlerin asıl amacı mahalle halkı arasında bilinen yasak bir ilişkinin alenileştirilmesi ve üzerinde açıkça konuşulur hale getirilmesini sağlamaktı. Ayrıca olayın mahalle halkı tarafından duyurulmasındaki diğer bir amaç da iki kişi arasında yaşandığı iddia edilen mahrem bir ilişkiyi kamusal alana taşıyarak mahkemeyi bu meseleden haberdar etmekle ilgiliydi. Mahalle halkının bunu yapmasındaki üçüncü bir amaç ise evlilik dışı sayılan bu tür yasak ilişkileri ifşa ederek, bu ve buna benzer maceralara girişmeyi göze alacak olanlara gözdağı vermekle de doğrudan ilişkiliydi. Çünkü mahalle ahalisi bu olayların yaygınlaşmasını istemiyor ve mahkemeyi bu türden olaylar için caydırıcı bir unsur olarak kullanmayı biliyordu. Mahalle ahalisinin toplumsal hayat üzerindeki kontrolünün, mahremiyet sınırlarının çok daraldığı ve kişisel olanın en özel yanlarıyla mahalle ahalisi tarafından bilinebilecek duruma gelmesine yol açtığı söylenebilir (Artan, 1993, s. 107; Yılmaz, 2000, s. 94; Khoury, 2000, s. 111).

Mütesellim Mahmud Ağa sözlerine devam ederken Mezid ve İsmihan hakkında ayrıntılı bilgiler vermişti. Duyduğuna göre; 28 Ocak 1673 tarihinde gündüz vakti öğleden önce (kuşluk) Mezid İsmihan'ın mahallesine gelmiş, sokakta buluşup konuştuktan sonra İsmihan Mezid'i evine almıştı. Ardından İsmihan kapıyı kilitleyince zina yapacaklarını düşünen mahalle ahalisi tarafından yakalanarak Mahmud Ağa'ya teslim edilmişlerdi. ${ }^{2}$ Mahmud Ağa duyduklarının doğru olup olmadığının sorulmasını talep etti. Mezid ve İsmihan kendilerine yöneltilen bu suçlamaya ne demişlerdi? Bütün anlatılanlar her ikisinin de aleyhineydi. İşte Mezid'in cevabı; “Ben o gün İsmihan'ın evinin bulunduğu Ferhuniye 
Mahallesi'ne gittim ama asla onunla birlikte olmak gibi bir amacim yoktu". Bu ifadeyle Mezid kendisine yöneltilen suçu reddediyordu. İsmihan da aynı şekilde zina amacıyla bir araya geldiklerini kabul etmiyordu. ${ }^{3}$ Bu noktada kadı davaya, Müstecab oğlu İvaz Çelebi ve Veli Bey oğlu Nebi'nin konu hakkındaki bilgilerini dinleyerek devam etti. Mahkeme kaydı bu kişileri adil olanların ve adalet üzere hareket edenlerin en önde gelenleri manasındaki "udûl-i ricâl" olarak tanımliyordu. Bu tarz bir tanımlama mahkemenin adalet duygusu üzerinden bireyi tanımlama biçimi ile ilgili olup mahkemede tanıklık edenlerde bulunması gereken özellikler arasında yer alan adalet hissine sahip olma şartına yönelik bir atıf olarak da değerlendirilebilir. Bu kişiler Mahmud Ağa'nın anlatısını teyit eden sözler sarf ederek olaya bizzat şahit olduklarını belirtiyorlardı. ${ }^{4}$ İvaz Çelebi ile Nebi, Mezid ve İsmihan'ı, İsmihan'ın evine yakın bir sokakta buluşup, konuşup işaretleştikten sonra gizlice eve girerek kapıyı arkasından kilitlerken açı bir şekilde görmüşlerdi. Anlaşılacağı üzere iki kişi arasında yaşanan çok mahrem ve yasak bir ilişkiye mahalle halkı, çiftin nasıl buluştuğunu bilecek kadar vakıfdır. Bu durum Osmanlı mahallelerinin sosyal hayat üzerinden bireylerin hayatlarını irdelemeye uzanan sosyal otokontrol sisteminin bir sonucu olarak değerlendirilebilir. Bu sosyal otokontrol sistemi hakkında Dror Ze'evi; “erkek ve kadınları cinsiyetlerin temeli üzerine kurulu kısıtlayıcı bir sistemin parçalar olarak değerlendirmekte ve hukukun kamusal gözüyle birlikte, komşular ve akrabaların gözleri de, her iki cinsiyetin sinırları ihlal etmemelerini sağlamaya çalışıyordu" demektedir (Ze'evi, 2000, s. 215). Bu değerlendirme mahalle ahalisinin üstlendiği ahlak gözetmenliği rolünü gözler önüne sermektedir.

Tekrar mahkeme metnine dönecek olursak olaya tanık olanların sözleri Mezid ve İsmihan'ı muhtemelen çok zor durumda bırakmıştı. İvaz Çelebi ve Nebi ifadelerinin devamında evin kapısını zincirleyerek kadıya haber vermek istediklerinde Mezid ve İsmihan'ın kendilerinin varlığından haberdar olduklarını söylemişlerdi. İki kişi tarafından izlenildiklerini fark eden Mezid hemen kaçmaya yeltenmişti. Kaçmak için iki yolu vardı. Ya kapıdan çıkacaktı ya da duvardan atlayıp kaçacaktı. Ancak kapı zincirlenmişti. Mezid'in tek çaresi duvarın ardına geçmeyi başarmaktı. İsmihan Mezid'in kaçmasına yardımcı olmak için bir merdiven buldu ve duvara dayad $1 .{ }^{5}$ Ancak Mezid duvara çıktığında hiç beklemediği bir şeyle karşılaştı. Yan evin sakinlerini birden bire karşısında buldu. Bu kişiler ilk davada ismi geçen Nurullah'ın eşi ve kızları olmalıydı. Bu kanıya Nurullah'ın Mezid aleyhinde açtığı davada, Mezid'in duvar üzerinden kendi ailesini gözetlerken görüldüğünü ifade etmesinden varabiliriz. Ayrıca ikinci mahkeme kaydında da Mezid'in duvarın üzerine çıtığında kadınların kendisini engellediği belirtilmektedir. ${ }^{6}$ Mezid karşılaştı̆̆ı bu durum üzerine tekrar İsmihan'ın bahçesine indi. Bu defa da İsmihan kapıyı açıp Mezid'i kaçırmak istedi. Ancak kaçmasına fırsat kalmadan İvaz Çelebi ve Nebi onu yakalamıştı. Ayrıca İvaz Çelebi ve Nebi verdikleri ifadelerinde Mezid'i yakaladıklarında donunun ayaklarına kadar inmiş bir vaziyette olduğunu belirtmişlerdir. İvaz Çelebi ve Nebi son sözlerinde bunları anlatırken Mezid'i kadıya ihbar ettiklerini ve olaya anlattıkları şekilde şahit olduklarını ifade ettiler. Şahitlerin ifadesinden sonra olayı soruşturmakla görevli olan Müderris Mevlana

\footnotetext{
3 "... merkûm el-Hac Mezid mahalle-i mezbûreye vardığını ikrâr ve mezbûre İsmihan'ın menzilinde ikisi tenhâ kalup zinâya mübâşeret eylediklerini her biri inkâr ile cevâb viricek ..." Bk. (KŞS 16/128).

4 "... mezbûr el-Hac Mezid mezbûr İsmihân ile mezbûrenin menziline karîb zokakda biri birileriyle mükâleme ve işaret edüp ba'dehu ikisi mezbûre İsmihan'ın menziline girip kapuyu ardından kilidlediklerini biz alenen görmek ile ...". Bk. (KŞS 16/128). 5 “... menzil-i mezbûrun kapusun üstünden zincirleyüp hâkime haber virmek murâd eylediğimizde her biri âgâh olup mezbûre İsmihan divarına nerdübân koyup merkûm el-Hac Mezid divar üzerine çıkup firâra kasd eyledikde ...", Bk. (KŞS 16/128).

6 ".... Merkûm el-Hac Mezid divar üzerine çıkup firâra kasd eyledikde işbu hazır-ı bi'l-meclis olan el-Hac Nurullah'ın menziline muttasıl olmak ile ol-tarafdan nisvân tâ'ifesi men' eyledikde ..." Bk. (KŞS 16/128).
} 
Mehmed Efendi söylenenleri kaydetti ve Çukadar Abdülbaki Beşe vasıtasıyla mahkemeye iletti. Mahkeme kaydının sonunda bu olaya dair nasıl bir karar verildiğini anlamamızı sağlayacak herhangi bir ifadeye rastlayamıoruz. ${ }^{7}$ Ancak Mezid'in donunun ayaklarına kadar inmiş olması tanıkların ve mahalle ahalisinin zina isnadına bir delil olarak gösterilebilir mi? İslam hukukuna göre zina aralarında şer'i bir akid yani nikah bulunmayan bir erkekle kadının kendi istekleriyle cinsel birleşmede bulunmaları şeklinde tarif edilmiştir (Bilmen, 1968, s. 197). Yine İslam hukukuna göre kadın ve erkeğin zina yaptığının ispatlanmasında en az dört erkek şahide ihtiyaç olup bunların aynı mecliste şahitlik yapmalarına, olayı ayrıntılı ve birbirleriyle çelişmeden anlatmalarına, şahitliklerini asaleten yapmalarına ve kocanın karısı aleyhine şahitlik yapmaması şartlarına bağlıdır (Bilmen, 1968, s. 212; Boynukalın, 1995, s. 79-85; Çalışkan, 1994, s. 79-83; Esen, 2013, s. 442; Imber, 2017, s. 506). Dört şahit kuralının alternatifi zina yapan kişinin suçunu dört ayrı mecliste ikrar etmesidir (Habergetiren \& Yiğitoğlu, 2016, s. 277; Imber, 2017, s. 507; Mutaf, 2008, s. 577; Üçok, 1946, s. 135). Ayrıca zina fiilinin gerçekleştiğini ispat edebilmek için şahitlerin, fıkıh kitaplarında anlatıldığı şekliyle, erkeğin cinsel organının kadının fercine "diviti hokkaya sokup çıkarır gibi, sürme kabına girip çıkan mil gibi ya da kınına girip çıkan kılıç gibi" girip çıktığını görmüş olmaları gerekmektedir (Baer, 2016, s. 96; Imber, 2017, s. 508). O halde İsmihan ve Mezid'in öyküsünde gerek şahitlerin sayısının iki oluşu ve gerekse şahitlerin ifadelerinin zina fiilinin gerçekleştiğini söylemekten çok uzak olması olayın faillerinin zina suçunu işlemekten yargılanamayacaklarını düşündürebilir. Ancak evli olmayan bir kadının evine giren bir erkek ile onu evine alan kadının cezasının ne olduğu/olabileceği merak edilebilir. Bu konuda bizim ele aldığımız olay örgüsüne uygun olarak hem kanunname hem de fetvalarda birtakım hükümler yer almaktadır:

\section{Bir kadının bir adamla gayri meşru aşk ilişkisi yaşadığı söylentisi varsa ve şahitler onları "tenha bir noktada" gördüklerine şahitlik ederlerse çift zina için konulmuş olan para cezasını öder ve tazir cezası alır. ${ }^{8}$ \\ Mesele: "Zeyd'i, filan kadının evinde bulduk" diye iki kişi şahitlik etse Zeyd'in cezası ne olur? Cevap: Şiddetli tazir ve hapisle cezalandırlmalıdır (Düzdağ, 2012, s. 203; Imber, 2017, s. 532).}

Ebussuud Efendi'nin fetvalarından ve Kanuni Sultan Süleyman dönemi kanunnamelerinden alınan bu bilgiler bize neleri ifade ediyor ya da düşündürüyor? Fetvada örneklenen kişinin İsmihan'ı betimlemesi, kanunnamede ise Mezid'in hareketinin tarif edilmesi esasen kadı'nın konuyla ilgili karar verirken hem şer'i hem de örfi hukukun kaynaklarından beslendiğini göstermesi bakımından önemlidir. Ancak bizim dikkat çekmek istediğimiz asıl konu bu örnek üzerinden mahkeme metinlerinin oluşturulmasında takip edilen usul üzerine çıkarımlar yapılabileceğidir. Yukarıda mahkeme metinlerinin kâğıda dökülmesinde kadı ve kâtibin üstlendikleri rolden bahsederek kadı'nın yargılama yönteminin gereklerinin yerine getirildiğini gösteren öğeleri metne yerleştirdiğini

\footnotetext{
7 "... yine mezbûrenin menziline inüp ve mezbûre kapuyu silküp ve açup merkûm el-Hac Mezid'i kaçırmak murâd eyledikde biz görüp merkûm el-Hac Mezid'i ahz eylediğimiz mahalde donu ayă̆ına nüzul idüp tekrâr yine bağladı bu halde ahz idüp hâkime ihbâr eyledik biz bu husûsa bu vech üzere şâhidleriz şehâdet dahî ideriz deyu edâ-i şehâdet-i şer'iye eylediklerinde şehâdetleri hayyiz-i kabûlde vâkı'a oldukdan sonra mevlânâ-yı mezbûr mahallinde istimâ' ve tahrîr idüp ba'dehu ma'â irsâl olunan Çukadar Abdulbaki Beşe ile meclis-i şer'a gelüp haber virmesiyle mûcibiyle hükm bir le mâvaka'a bi't-taleb ketb olundu ..." Bk. (KŞS 16/128).

8 "Ĕ̆ger bir avretin bir er ile adı çekilse, ikisini bir halvet yerde görüb şahâdet eyeleseler, kâdî ta'zîr ede; zinâ kinlı̆̆ın kemâ kân alalar" Bk. (Akgündüz, 1992, s. 297; Imber, 2017, s. 514).
} 
söylemiştik. Konuya bu açıdan bakılacak olursa kanunnameden alınan "bir kadının bir adamla gayri meşru aşk ilişkisi yaşadığ söylentisi varsa" ifadesinin benzer bir versiyonu "Mezid sürekli olarak İsmihan'ın evine gelir" şekline bürünerek mahalle ahalisi tarafından dile getirilmişti ya da bu ifade Mahmud Ağa'nın anlatısında "iki seneden beri ilişkileri olduğunu işittim" şeklinde mahkeme kayıtlarında yer almıştı. Yine kanunnameden devam edecek olursak "tenha bir yer" ifadesi metinde "İsmihan'ın evi" olarak betimlenmişti. İsmihan'ın işlediği fiilden dolayı hak ettiği cezaya çarptırılabilmesi için deliller ve şahitlerin ifadesini kullanan kadı, kanunnamede yer alan hükümden hareketle ince ayrıntıları içinde barındıran kelimeleri davanın sorgulanmasına mahal bırakmayacak şekilde metin içerisine yerleştirmişti. Peki kadı İsmihan'a nasıl bir ceza takdir etmişti? Kanunnameden aldığımız örneğin son kısmından anlaşılacağı üzere İsmihan'ın zina için konulan para cezasını ödeyeceği ve tazir cezasına çarptırılacağı düşünülebilir. İsmihan'ın dul bir kadın olduğu ihtimali üzerinden hareket edecek olursak kanun gereğince ekonomik durumunun çok iyi olduğu tespit edilirse 100, orta halli ise 50, kötü ise 30 akçe para cezası ödemiş olmalıdır. Ayrıca kanunnamede yer alan çift kelimesi Mezid'in de para cezası ödeyeceğine -evli ise ekonomik durumuna göre aşamalı olarak 40, 50, 100, 200, 300 akçe; bekar ise 30, 50, 100 akçe- delildir (Acar, 2001, s. 62-63; Akgündüz, 1992, s. 295-296; Pierce, 2000, s. 163; Ze'evi, 2008, s. 70-78). İsmihan para cezasina ek tazir olarak sopa cezasına -kadı'nın takdirine göre değişmekle birlikte Hanefi mezhebine göre sopa cezasinın üst sinırı olarak 39, 75, 79, 99 sayllar verilmektedir- çarptırılmış olması muhtemeldir (Başoğlu, 2011, s. 201; Üçok, 1946, s. 135).

Peki kadı, Ebussuud'un fetvasında yer alan sembolik karakter Zeyd'in vücut bulmuş hali olan Mezid'in işlediği suça karşı vereceği cezayı meşrulaştıracak hangi öğeleri seçmişti? Fetvada "Zeyd'i filan kadının evinde bulduk" ifadesi şahitlerin dilinden "Mezid'i donu ayaklarına inmiş bir şekilde İsmihan'ın evinde yakaladık" biçiminde çıkmıştı. Ayrıca fetvada bu duruma iki kişinin şahitliği de eklenmişti. Hatırlanacağı üzere İsmihan ve Mezid aleyhinde tanıklık edenler İvaz Çelebi ve Nebi ikilisiydi. Fetvadaki anlatıya göre Mezid şiddetli sopa ve hapis cezası almış olmalıdır. Bu durumda İslam hukuku cinsler arasında ayrım yapmamaktadır. Aynı cezanın İsmihan'a da verilmesi gerekmektedir. İşte burada dayak cezalarının kanunnamelerde para cezası verilmesi devreye girmiş olabilir. Buradan hareketle Mezid ve İsmihan para cezasının yanı sıra mahallelerinden ihraç edilmiş olma ihtimallerini de düşünmek gerekmektedir. Çünkü zina suçunun cezaları arasında kişinin ikamet ettiği mahalleden sürgün edilmesi de vardır (Konan, 2011, s. 155). Aleni bir biçimde Mezid'in İsmihan'ın evinde yakalanması mahallelinin ihraç isteklerini haklı konuma getirmiş olabilir.

\section{SONUÇ}

Osmanlı toplumunda kadın gündelik yaşamında kendisine mahrem olan erkekler dışındaki erkeklerle ilişkilerinde belirli kurallara uymak zorundadır. Bu kurallara uymayanların tutumları ahlaksızlıkla ilişkilendirilir ve davranışları ahali tarafından sorgulanır hale gelir. Mahkeme kayıtlarından anlaşıldığı üzere toplumsal normların dışına çıanlar muhtemelen mahalle ahalisinin zihninde olumsuz bir intiba bırakmaktadır. Aykırı davranışları ile ön plana çıkn bireyler töhmetli olarak addediliyor ve kendilerine isnat edilen suçlardan aklanıncaya kadar töhmetli olarak yaşamaya devam ediyorlardı. İsmihan örneğinde de görüldüğü gibi bir kadının gayrimeşru gönül ilişkileriyle isminin anılması, aralarında evlilik akdi olmadığı halde Mezid ile görüşmesi ve tanıkların ifadelerine atfen bu görüşmeleri sürekli hale getirmiş olması İsmihan'ın töhmetli olduğunu ve mahalle ahalisi tarafından İsmihan'ın ahlaki kurallara uymayan bir kadın olarak tanındığını göstermektedir. 
Mahallenin ortak sorumluluklar üzerine kurulmuş olduğu düşünülecek olursa toplumsal ahlaki değerlerin muhafazası ve aile birliklerinin sarsılmasını engellemek mahalle sakinlerinin üstlendiği tanımlanmamış bir görev -sosyal otokontrol- olarak kabul edilebilir. Mahalle ahalisi tarafından üstlenilen bu görev İsmihan ve Mezid meselesini mahkemeye taşıyacak kadar güçlüdür. Birey, mahalle ve mahkeme üçgeninde yaşanılan olaylar bir yönüyle de mahrem/özel alandan kamusal alana taşınan çok boyutlu bir hadisenin izlerini taşımaktadır. Ayrıca ev, sokak, mahalle ve oradan da şehre doğru genişleyen insan ilişkileri göz önünde bulundurulduğunda bu ilişkilerin toplumsal tarihin gündelik yaşama bakan yönlerini oluşturduğu görülecektir.

Gerek tanıkların anlatıları gerekse fetva ve kanunnamelerdeki ifadeler bir bütün olarak ele alındığında ev ve evin kapsadığı alanın (bahçe, duvar, sokak kapısı vs.) bireyin mahrem alanını ifade ettiği görülür. Yine tanıkların ifadelerinden ulaşılabilecek önemli bir sonuç mahrem alanın izlenebilir ve gözlemlenir olduğudur. Bu bağlamda mahrem alan ile kamusallık arasında karşılıklı bir bağın olduğunu söylemek mümkündür. İsmihan ve Mezid arasında yaşananlar insanların özel alanlarının diğerleri tarafından ayrıntılı bir şekilde izlenebildiğini göstermektedir. İki kişi arasında yaşanan mahrem ve yasak bir ilişkiye mahalle halkı, çiftin nasıl buluştuğunu bilecek kadar vakıf olabilmektedir. Verdiğimiz örnekte yaşanan olayın ortaya çıkmasının nedeni olan mahalle halkının ifşaatları bir yasak aşkın alenileştirilmesi ve üzerinde açıkça konuşulur hale getirilmesi ile ilişkilidir. Mahalle halkı hukuki hakkını kullanarak mahkemeyi devreye sokmuştur. Bu davranışın altında kendi özel alanlarını koruma kaygısı aranabilir. Ancak burada üzerinde durulması gereken konu kamusal alana aksettirilmek istenen mahrem bir olayın varlığıdır. Olayın mahalle halkı tarafından duyurulması ile birlikte vaka mahkemeye intikal etmiştir. Bu durum kamusal alana taşınan mahrem bir ilişkiyi otoritenin de dikkatine sunmaktır. Mahalle halkının Mezid'i şikâyet etmesi açıkça Konya kadısına yönelik bir görev çağırısıdır. Bu görev çağırısının temelinde mahalle ahalisinin bu ilişkiyi onaylamadığını gösteren ve onu alenileştirmeyi amaçlayan bir hareket yatmaktadır. Ayrıca iki kişi arasında yaşanan yasak aşk gibi mikro bir olayın hukuk, ahlak, birey-mekân ilişkisi ve gündelik yaşam gibi makro alanlara taşan yanları ile birlikte değerlendirilmesi Konya şehir hayatını oluşturan unsurların açıklanmasına katkı sunması bakımından dikkate değerdir.

\section{SUMMARY}

Court records kept in the Ottoman courts are used as the main source in social and local history studies. The fact that these registers contain records of various issues among people of all levels in the center and in the provinces provides inferences about how and why people applied and used the courts such as issues of everyday life, interpersonal relations, and social life. At the same time, these records reveal how Ottoman law was applied in court. Within this context, in this study, the issues of daily life, neighborhood, court, publicity and privacy have been evaluated through an incident reflected in the court records. The discussed incident which took place in the second half of the 18th century focuses on the forbidden relationship of İsmihan and Mezid who act against social moral norms and neighborhood control in Konya. In addition, the fact that Mezid was caught in İsmihan's house, and the way the court and social control mechanism worked on what happened after that was also examined.

SEFAD, 2020; (43): 421-434 
The events related to the entrance of a man into the house of a lone Muslim woman have turned into a multidimensional story that reflects the structure of the Ottoman neighborhood and the functioning of the kadi court. When the forbidden love between Ismihan and Mezid is followed by residents of the neighborhood and the reaction of the neighborhood to such actions threatening their public spaces are considered as a whole, it can be important in terms of demonstrating that the behavior of individuals is subjected to control of both the residents and the court, in other words, the state authority. In Ottoman society, women have to follow certain rules in their relations with men. Attitudes of those who do not obey these rules are associated with immorality, and their behavior is questioned by the public. As it can be seen in the example of Ismihan, the fact that a woman was mentioned with illegitimate heart relationships, that she had met with Mezid even though there was no marriage contract, and that these visits were constantly made according to the statements of the witnesses indicates that İsmihan was recognized as a woman who did not comply with moral rules. Considering that the neighborhood is built on common responsibilities, protecting social moral values and preventing the threat to family unions can be considered as an undefined task that neighborhood residents undertake. This duty, which is undertaken by the local people, is strong enough to bring the issue of İsmihan and Mezid to the court. The events in the triangle of the individual, the neighborhood and the court bear the traces of a multidimensional event that has been carried from the private / public space to the public space.

When both the narratives of the witnesses and the expressions in fatwa and legislations are taken as a whole, it is seen that the space covered by the house and the yard of house (garden, wall, street gate, etc.) expresses the privacy of the individual. Another important conclusion that can be reached from the statements of the witnesses is that the intimate space can be monitored and observed. In this context, it is possible to say that there is a mutual connection between the private space and publicity. What happened between İsmihan and Mezid shows that the private spaces of people can be followed in detail by others.

The people of the neighborhood can have enough evidence to know how the couple meet in such a forbidden relationship between two people. The revelations of the people of the neighborhood, which is the reason for the occurrence of the incident in our example, are related to the publicizing of a forbidden love and making it openly spoken. The people of the neighborhood have put the court into effect by using their legal right. Under this behavior, anxiety to protect their private spaces may be sought. However, the issue that needs to be emphasized here is the existence of a private event that is intended to be reflected in the public sphere. With the announcement of the incident by the people of the neighborhood, the case was submitted to the court. This brings an intimate relationship to the public space and to the attention of the authority. It is clearly a call for duty of the Kadi when the people complain about Mezid at the court. On the basis of this call for duty lies a movement that demonstrates that the neighborhood community does not approve of this relationship and aims to publicize it. 


\section{KAYNAKÇA}

\section{I-Konya Şer'iye Sicili (KŞS)}

Defter No: 16

\section{II-Kitap ve Makaleler}

Acar, İ. (2001). Osmanlı Kanunnameleri ve İslam Ceza Hukuku (1). Dokuz Eylül Üniversitesi Ilahiyat Fakültesi Dergisi(XIII-XIV), 53-68.

Akgündüz, A. (1992). Osmanlı Kanunnâmeleri ve Hukuki Tahlilleri (Cilt I, IV). İstanbul: Fey Vakfi Yayınları.

Aköz, A. (2016). Osmanlı Toplumunda Mahremiyet ve Mekan. Uluslararası Osmanlı Araştırmalarında Yeni Eğilimler Kongresi Bildiri Kitabı 7-9 Ekim 2016, (s. 41-56). Saraybosna.

Artan, T. (1993). Mahremiyet: Mahrumiyetin Resmi. Defter(20), 91-115.

Aydın, M. A. (2003). Mahkeme. Türkiye Diyanet Vakfı İslam Ansiklopedisi. (Cilt 27), s. 341-344. İstanbul: Türkiye Diyanet Vakfı.

Baer, M. D. (2016). Atmeydanı'nda Ölüm 17. Yüzyıl İstanbul'unda Toplumsal Cinsiyet, Hoşgörü ve İhtida. (P. Yanardă̆, Çev.) Koç Üniversitesi Yayınları.

Başoğlu, T. (2011). Tâ'zîr. Türkiye Diyanet Vakfı İslam Ansiklopedisi. (Cilt 40), s. 198-202. İstanbul: Türkiye Diyanet Vakfı.

Bilmen, Ö. N. (1968). Hukûk-ı İslâmiye ve Istılahât-ı Fıkhiye Kamusu (Cilt III). İstanbul: Bilmen Yayınevi.

Boynukalın, M. (1995). İslam Hukukunda Zina Suçunun Mahiyeti ve Cezası (Basılmamış Yüksek Lisans Tezi). İstanbul, Marmara Üniversitesi Sosyal Bilimler Enstitüsü.

Çalışkan, İ. (1994). İslam Hukukunda Zina Suçunun Mahiyeti ve Cezası. Ankara Üniversitesi İlahiyat Fakültesi Dergisi, 33(1), 61-101.

Çetin, C. (2014). Osmanlı Toplumunda Mahalleden İhraç Kararları ve Tatbiki: Konya Örneği (1645-1750). History Studies, 6(6), 43-70.

Çetin, C. (2019). Erken Modern Dönem Osmanlı Toplumunda Namus Algısına Dair Bazı Gözlemler (Konya Örneği). Selçuk Üniversitesi Türkiyat Araştırmaları Dergisi (SUTAD), 45, 61-86.

Düzdağ, E. (2012). Kanunî Devri Şeyhülislâmı Ebussuud Efendi Fetvaları. İstanbul: Kapı Yayınları.

Ergenç, Ö. (1984). Osmanlı Şehrindeki "Mahalle"nin İşlev ve Nitelikleri Üzerine. Osmanlı Araştırmalarl(IV), 69-78.

Ergenç, Ö. (2015). Klasik Dönem Osmanlı Toplumunda Mekân, Mahremiyet ve Cinsiyet İlişkileri Üzerine. Osmanlı'dan Günümüze Cinsiyet, Mahremiyet ve Mekân Çalıştay Tebliğ ve Müzakereleri 8 Haziran 2013 (s. 13-19). İstanbul: Türkiye Diyanet Vakfı.

Esen, H. (2013). Zina. Türkiye Diyanet Vakfi İslam Ansiklopedisi. (Cilt 44), s. 440-444. İstanbul: Türkiye Diyanet Vakfı.

Habergetiren, Ö. F., \& Yiğitoğlu, M. (2016). Yahudilik ve İslam'da Zina Suçu ve Cezası. İnsan ve Toplum Bilimleri Araştırmaları Dergisi, 5(2), 20-31.

Habermas, J. (2003). Kamusallığın Yapısal Dönüşümü. (T. Bora, \& M. Sancar, Çev.) İstanbul: İletişim.

SEFAD, 2020; (43): 421-434 
Imber, C. (2017). Osmanlı Hukukunda Zina. (M. Midilli, Çev.) İslam Hukuku Araştırmaları Dergisi, (29), 505-538.

Kaplanoğlu, R. (2012). Mahalle Hukukunda "Hüsn-i Hâl", "Sû-i Hâl" ve Mahalleden İhraç Kararları. Bursa Araştırmaları Dergisi(36), 49-58.

Kavaklı, S. (2013). Ölüm ve Yaralanma Olaylarıyla İlgili Keşif Hüccetlerinin Değerlendirilmesi: Onyedinci Yüzyıl Amasya Şer'iyye Sicillerinden Örneklerle. History Studies, 5(3), 117-142.

Kaya, S. (2008). Sak. Türkiye Diyanet Vakfi İslam Ansiklopedisi. (Cilt 35), s. 586-587. İstanbul: Türkiye Diyanet Vakfı.

Khoury, D. R. (2000). Terlikler Kapıda Mı, Kapalı Kapılar Ardında Mı: Ev İçinde ve Kamusal Mekânda Musullu Kadınlar. M. C. Zilfi (Ed.), Modernleşmenin Eşiğ̈inde Osmanlı Kadınları (s. 101-121). Tarih Vakfı Yayınları.

Konan, B. (2011). Osmanlı Hukukunda Tecavüz Suçu. OTAM(29), 149-172.

Kütükoğlu, M. (2018). Osmanlı'nın Soyo-Kültürel ve İktisadî Yapısı. Ankara: Türk Tarih Kurumu.

Mutaf, A. (2008, Summer). Teorik ve Pratik Olarak Osmanlı'da Recm Cezası: Bazı Batı Anadolu Şehirlerindeki Ugulamaları. Turkish Studies, 3(4), 573-598.

Ortaylı, İ. (1994). Hukuk ve İdare Adamı Olarak Osmanlı Devletinde Kadı. Ankara: Turhan Kitabevi.

Pierce, L. (2000). Ekberiyet, Cinsellik ve Toplum Düzeni: Toplumsal Cinsiyetle İlgili Osmanlı Söz Dağarcığı. M. C. Zilfi (Ed.), Modernleşmenin Eşiğginde Osmanlı Kadınları (s. 161-187). Tarih Vakfı Yayınları.

Taş, H. (2007). Osmanlı'da Şikayet Hakkının Kullanımı Üzerine Düşünceler. Memleket, 2(3), 187-205.

Tekgül, N. (2013). Modernite Öncesi Osmanlı Toplumunda "Mahremiyet" Halkaları. Ü. Ekin (Ed.), Prof. Dr. Özer Ergenç'e Armağan (s. 411-433). İstanbul: Bilge Kültür Sanat.

Tok, Ö. (2005). Kadı Sicilleri Işığında Osmanlı Şehrindeki Mahalleden İhraç Kararlarında Mahalle Ahalisinin Rolü (XVII. ve XVIII. Yüzyıllarda Kayseri Örneği). Erciyes Üniversitesi Sosyal Bilimler Enstitüsü Dergisi(18), 155-173.

Tutar, A. Y. (2018). 16 Numaralı Konya Şer'iye Sicili (1083-1083 / 1672-1673) Değerlendirme ve Transkripsiyon, (Basılmamış Yüksek Lisans Tezi). Konya, Selçuk Üniversitesi Sosyal Bilimler Enstitüsü.

Üçok, Ç. (1946). Osmanlı Kanunnamelerinde İslam Ceza Hukukuna Aykırı Hükümler. Ankara Üniversitesi Hukuk Fakültesi Dergisi, 3(1), 51-82.

Yağcı, Z. G. (2005). Osmanlı Taşrasında Kadınlara Yönelik Cinsel Suçlarda Adalet Arama Geleneği. Kadın Araştırmaları Dergisi, VI(2), 51-82.

Yılmaz, F. (1995). XVI. Yüzyılda Edremid Kazası, (Basılmamış Doktora Tezi). İzmir, Ege Üniversitesi Sosyal Bilimler Enstitüsü.

Yılmaz, F. (2000). XVI. Yüzyılda Osmanlı Toplumunda Mahremiyetin Sınırlarına Dair. Toplum ve Bilim, 92-109.

Ze'evi, D. (2000). 17. Yüzyılda Bir Osmanlı Sancağı'nda Toplum ve Ekonomi. (S. Çağlayan, Çev.) Tarih Vakfı Yayınları.

Ze'evi, D. (2008). Müslüman Osmanlı Toplumunda Arzu ve Aşk. (F. Aytuna, Çev.) Kitap Yayınevi. 